\title{
PENGARUH MEDIA SOSIAL INSTAGRAM DALAM MENGIKLANKAN MAKANAN CEPAT SAJI DAN DAMPAK BAGI KESEHATAN PADA REMAJA
}

\author{
Wuri Handayani ${ }^{1 *}$, Siti rara oyi pinasti ${ }^{2}$, Firda Rahayu ${ }^{3}$, dan Marhaeni Fajar Kurniawati ${ }^{4}$. \\ 1,2,3 Mahasiswa Program Pascasarjana, Magister Ilmu Komunikasi, Universitas Islam Kalimantan Muhammad \\ Arsyad Al Banjari, Jl. Adhyaksa, Jl. Kayu Tangi 1 Jalur 2 No.2, Sungai Miai, Kec. Banjarmasin Utara, Kota \\ Banjarmasin, Kalimantan Selatan 70123, Indonesia. \\ ${ }^{4}$ Dosen Program Pascasarjana, Magister Ilmu Komunikasi, Universitas Islam Kalimantan Muhammad Arsyad \\ Al Banjari, Jl. Adhyaksa, Jl. Kayu Tangi 1 Jalur 2 No.2, Sungai Miai, Kec. Banjarmasin Utara, Kota \\ Banjarmasin, Kalimantan Selatan 70123, Indonesia. \\ Email: ${ }^{1}$ wurihandayani.st@gmail.com, ${ }^{2}$ mbakoyi@gmail.com, 3Firdarahayu2106@gmail.com. \\ ㅆmarhaeni.akbar@gmail.com
}

\begin{abstract}
ABSTRAK
Kebutuhan gizi remaja perlu diperhatikan karena pada masa remaja terjadi pertumbuhan dan perkembangan yang cepat. Kebiasaan makan yang tidak sehat mempengaruhi asupan gizi remaja, seperti makanan cepat saji banyak dikonsumsi remaja. Pada saat semua serba modern, remaja menginginkan semuanya serba cepat, termasuk dalam memilih makanan yaitu makanan cepat saji dikenal masyarakat sebagai junk food. Junk food diartikan sebagai makanan sampah atau makanan yang tidak memiliki nutrisi bagi tubuh. Makanan junk food tidak hanya sia-sia, tetapi juga dapat merusak kesehatan. Makanan cepat saji berasal dari negara barat yang memiliki kandungan lemak dan kalori yang tinggi. Banyak faktor yang mempengaruhi remaja mengonsumsi makanan cepat saji, dibahas berdasarkan artikel penelitian maupun referensi buku antaralain diantaranya adalah rasa, harga, tempat yang nyaman, maupun pengaruh teman sebaya. Makanan cepat saji dapat meningkatkan risiko beberapa penyakit, seperti obesitas, diabetes, hipertensi, dan gangguan lemak darah atau dislipidemia. Obesitas atau kegemukan banyak dialami oleh anak-anak, remaja, hingga dewasa. Namun, dari obesitas yang dialami oleh seseorang, maka akan meningkatkan faktor risiko seseorang untuk menderita penyakit degeneratif lainnya, seperti tekanan darah tinggi, diabetes, kanker, penyakit jantung, dan stroke.
\end{abstract}

Kata Kunci: remaja, makanan cepat saji, obesitas

\section{PENDAHULUAN}

\subsection{Latar Belakang}

Pertumbuhan manusia di usia 10 tahun hingga 18 tahun disebut sebagai remaja. Hal ini disebutkan dalam Peraturan Menteri Kesehatan nomor 25 tahun 2014. Pada usia tersebut pertumbuhan remaja terjadi lebih pesat dan adanya perubahan kematangan fisiologis yang berhubungan dengan masuknya masa pubertas, sehingga remaja harus memiliki asupan gizi dan nutrisi yang baik dan cukup.

\subsection{Tinjuan Pustaka}

Masa remaja merupakan masa yang sangat rawan atas kebutuhan zat gizi. Pemenuhan zat gizi yang seimbang diperlukan oleh kelompok remaja untuk pertumbuhan, perkembangan dan menjalankan kegiatan jasmani yang meningkat.(Maya Amaliyah, Rahayu Dewi Soeyono, Luthfiyah Nurlaela, dan Dwi Kristiastuti, 2021: 129-137).

\subsection{Metodologi Penelitian}

Adanya pertumbuhan dan perkembangan di usia remaja ini membuat remaja perlu memperhatikan asupan makanannya. Banyaknya aktivitas fisik memerlukan kalori, mikronutrien, protein pada remaja. Proses metabolisme tubuh pada remaja akan terganggu jika kurang mengonsumsi makanan secara kuantitas dan kualitas yang dikhawatirkan akan menyebabkan penyakit pada tubuh.

Berbeda dengan zaman dahulu, masa kini banyak sekali pedagang yang menjual makanan cepat saji atau fast food. Restoran cepat saji ini mudah sekali ditemukan di tiap sudut daerah, mengingat remaja adalah makhluk yang sedang aktif berinteraksi dengan usia sebayanya, tak jarang remaja terlihat di restoran cepat saji. jika dimakan terlalu sering, makanan cepat saji yang mengandung lemak dan kalori yang tinggi akan menyebabkan obesitas atau kegemukan pada remaja.

Fast food juga dikenal sebagai junk food yang berarti makanan yang tidak memiliki gizi atau nutrisi yang baik untuk tubuh hingga dapat menyebabkan beberapa masalah yakni diabetes, hipertensi, stroke, penyakit jantung koroner dan kanker. tidak dapat dipungkiri makanan cepat saji ini memiliki rasa yang 
sedap sehingga remaja lebih tertarik mengkonsumsi fast food daripada makanan bernutrisi lainnya.

Disamping tersebar luasnya restoran makanan cepat saji, para marketing restoran tersebut juga berlombalomba mengiklankan produk mereka di media sosial salah satunya instagram. dinilai lebih efektif dalam menjangkau masyarakat, instagram yang memiliki konsep pemaparan foto dan videografi dianggap lebih gampang dalam mengiklankan produk. Apalagi masa kini remaja identik dengan smartphone atau ponsel pintar sehingga para remaja mudah mengakses instagram. jika restoran memiliki promo atau produk baru, mereka akan posting hal tersebut di instagram.

Dengan penjelasan di atas, maka jurnal ini akan membahas tentang pengaruh media sosial instagram dalam mengiklankan produk makanan cepat saji beserta dampak kesehatan pada remaja yang sering mengonsumsinya. media sosial instagram.

\section{PEMBAHASAN}

Penelitian Eryta (2013) "sebagai media komunikasi pemasaran, instagram merupakan aplikasi media sosial yang kehadirannya semakin dimaksimalkan. instagram memberi peran penting bagi pelaku bisnis yang menggunakannya sebagai media pemasarannya, diantaranya adalah instagram sebagai media promosi yang dianggap efektif oleh informan, yang edia instagramsebagai media komunikasi antara pelaku bisnis dengan para konsumennya. dan yang terakhir, instagram memberikan dampak terhdap peningkatan penjualan pada bisnis mereka".

\section{Iklan Online}

Menurut Erdogmus dan Cicek (2012) pemasaran media sosial didefinisikan sebagai proses yang memberdayakan individu untuk mempromosikan situs web, produk atau jasa mereka melalui saluran sosial online dan memasuki sebuah komunitas yang jauh lebih besar yang mungkin belum tersedia melalui saluran tradisional.

Menurut Lim et, al (2011) ada beberapa variabel yang bisa digunakan untuk mengukur efektifitas suatu iklan online yaitu ad recall, online advertising awards, brands awereness, ctr (click throught rates), dan attitude towards the ad.

Dampak konsumsi makanan cepat saji

1. Obesitas atau kegemukan

Sering konsumsi makanan cepat saji pada remaja akan berisiko mengalami kegemukan. risiko sebesar 2,27 kali lebih tinggi akan dialami remaja yang sering konsumsi makanan cepat saji daripada tingkat konsumsi yang rendah. Gaya hidup konsumsi makanan cepat saji menjadi faktor kegemukan yang dialami remaja. karena fast food mengandung tinggi lemak dan kalori tetapi kandungan serat,vitamin dan mineral nya rendah. contohnya, burger, pizza, kentang goreng. Gizi berlebih pada tubuh menyebabkan kegemukan atau obesitas. sehingga jaringan dalam bentuk lemak tersimpan karena konsumsi energi yang berlebih.

2. Meningkatkan faktor risiko hipertensi atau tekanan darah tinggi, kandungan garam yang dimiliki oleh fast food dapat meningkatkan sekresi enzim dan air liur, sehingga meningkatkan minat untuk mengkonsumsi ulang. tingkat lemak jahat dan natrium membuat keseimbangan sodium dan potasium dalam tubuh terganggu yang menyebabkan hipertensi.

Penelitian di Amerika menunjukkan konsumen yang mengonsumsi fast food dalam porsi besar, dan dalam frekuensi 2-3 kali tiap minggu, maka berakibat pada hipertensi.

Penelitian di Yogyakarta menunjukkan kebiasaan makan fast food dan kejadian hipertensi memiliki hubungan yang signifikan. semakin sering, maka semakin berpeluang besar terjadinya hipertensi pada konsumen. Salah satu penyebab hipertensi yakni obesitas. jika berat badan naik secara, maka hipertensi bisa terjadi.

3. Meningkatkan faktor risiko diabetes

Sering mengonsumsi makanan cepat saji adalah salah satu penyebab utama meningkatnya trend masalah kesehatan, termasuk kejadian diabetes. Penelitian di Singapura menunjukkan bahwa orang yang mengonsumsi makanan cepat saji khas negara barat dengan frekuensi yang sering memiliki risiko lebih besar menderita diabetes melitus tipe 220. Saat ini telah banyak terjadi bahwa orang-rang masa kini tidak dapat melawan kebiasaan konsumsi makanan cepat saji yang dapat memberikan efek bagi kesehatan masyarakat. Sering mengonsumsi makanan cepat saji memiliki efek yang menyebabkan peningkatan gangguan metabolisme, termasuk kegemukan, resistensi insulin, diabetes tipe 2 , serta gangguan kardiovaskular. Salah satu penyebab diabetes adalah obesitas. Sedangkan obesitas merupakan salah satu akibat dari makan makanan cepat saji yang pada umumnya memiliki kandungan gizi yang rendah. Risiko menderita diabetes melitus akan meningkat secara linier sesuai dengan peningkatan indeks massa tubuh (IMT). Orang dengan overweight atau IMT diatas rata-rata akan menigkatkan angka kejadian diabetes melitus sebesar 3-4 kali dibangingkan dengan orang dengan IMT yang normal. 
4. Meningkatkan faktor risiko kanker Konsumsi makanan cepat saji dapat meningkatkan risiko kanker, seperti kanker pada organ sistem pencernaan. Studi di Eropa menyebutkan bahwa konsumsi makanan cepat saji yang terlalu sering dapat meningkatkan risiko kanker kolorektal. Hal ini karena makanan cepat saji kuang mengandung serat, namun tinggi gula dan lemak. Selain itu, penelitian lain menunjukkan bahwa pria yang terlalu sering makan makanan yang digoreng lebih dari dua kali dalam satu bulan telah menunjukkan peningkatan risiko kanker prostat. Kebiasaan mengonsumsi makanan cepat saji merupakan faktor risiko kejadian FAM atau fibroadenoma mammae yang merupakan tumor jinak. Penderita FAM tersebut memiliki risiko 2 kali lebih besar menderita penyakit kanker payudara di kemudian hari23. Makanan cepat saji yang identik dengan daging yang dimasak dengan temperatur tinggi akan membentuk zat zat karsinogenik. Zat tersebut berpotensi membentuk tumor payudara dan akan meningkatkan risiko kanker.

5. Meningkatkan faktor risiko penyakit jantung Penyakit jantung menjadi salah satu penyebab kematian yang menakutkan. Ketersediaan makanan cepat saji yang tinggi dikaitkan dengan kematian dan penyakit jantung koroner akut, serta kelebihan berat badan dan obesitas yang tinggi. Salah satu penyebab terjadinya penyakit jantung adalah obesitas yang dialami seseorang. Hal ini karena obesitas meningkatkan risiko terjadinya penyakit jantung. Seseorang yang memiliki berat badan diatas rata-rata atau obesitas akan mengalami risiko penurunan fungsi jantung, termasuk fungsi jantung menjadi tidak normal.

Meningkatkan faktor risiko stroke Pola makan yang salah seperti makan makanan cepat saji dapat memicu terjadinya stroke pada usia muda. Hal ini disebabkan karena kandungan kolesterol yang tinggi. Kolesterol tidak baik bagi kesehatan, yaitu apabila terjadi penyumbatan pembuluh darah. Apabila mengenai pembuluh darah otak, maka akan mengakibatkan stroke. Kasus stroke di negara maju meningkat akibat kejadian kegemukan dan semakin banyaknya konsumsi makanan cepat saji pada masyarakat. Peningkatan jumlah penderita stroke di Indonesia juga identik dengan kegemukan akibat pola makan makanan yang mengandung tinggi lemak atau kolesterol.

\section{KESIMPULAN}

Makanan cepat saji merupakan makanan yang kurang baik bagi remaja apabila dikonsumsi terlalu sering. Banyaknya remaja yang mengonsumsi makanan cepat saji disebabkan karena beberapa faktor, diantaranya adalah pengetahuan, pengaruh teman sebaya, tempat nyaman untuk berkumpul, cepat dan praktis, uang saku, hargayang murah, dan brand dari makanan cepat saji. Apabila makanan cepat saji dikonsumsi secara berlebihan, maka akan berdampak pada kesehatan remaja. masalah kesehatan tersebut adalah obesitas, meningkatkan faktor risiko hipertensi, diabetes, kanker, penyakit jantung, dan stroke.

\section{PUSTAKA}

Adriani, M. \& Wirjatmadi, B. 2012. Peranan Gizi dalam Siklus Kehidupan. Jakarta : Prenamedia Group.

Almatsier, S. 2009. Prinsip Dasar Ilmu Gizi. Jakarta : PT Gramedia Pustaka Utama.

Arya, G. \& Mishra, S. 2013. Effects of Junk Food \& Beverages on Adolescent's Health - A Review Article. Journal of Nursing and Health Science Vol. 1 No. 6.

Bahadoran, Z., Mirmiran, P., Esfahani, F.H. \& Azizi, F. 2013. Fast Food Consumption and The Risk of Metabolic Syndrome After 3-years of Follow-up : Tehran Lipid and Glucose Study. European Journal of Clinical Nutrition.

Bahadoran, Z., Mirmiran, P. \& Azizi, F. 2015. Fast Food Pattern and Cardiometabolic Disorders : A Review of Current Studies. Health Promotion Perspective Vol. 5 No. 4.

Barasi, M.E. 2007. Nutrition At A Glance. Blackwell Publishing.

Damopolii, W., Mayulu, N. \& Masi, G. 2013. Hubungan Konsumsi Fastfood dengan Kejadian Obesitas pada Anak SD di Kota Manado. Ejournal Keperawatan Universitas Sam Ratulangi Manado Vol. 1 No. 1.

Depkes, Poltekkes. 2010. Kesehatan Remaja : Problem dan Solusinya. Jakarta : Penerbit Salemba Medika.

Goon, S., Bipasha, M.S. \& Islam, Md. 2014. Fast Food Consumption and Obesity Risk Among University Students of Bangladesh. Europan Journal of Preventive Medicine Vol. 2 No.6.

Khairiyah, E.L. 2016. Pola Makan Mahasiswa Fakultas Kedokteran dan Ilmu Kesehatan (FKIK) UIN Syarif Hidayatullah Jakarta Tahun 2016. Skripsi. Universitas Islam Negeri Syarif Hidayatullah Jakarta.

Kurdanti, W., Suryani, I., Syamsiatun, N.H., Siwi, L.P., Aditysnti, M.M., Mustikaningsih, D. \& Sholihah, K.I. 2015. Faktor-Faktor yang Mrmprngaruhi Kejadian Obesitas pada Remaja. Jurnal Gizi Klinik Indonesia Vol. 11 No. 04. 
Lestari, D. 2012. Perilaku Konsumsi Junk Food pada Siswa di SMA Negeri 1 Depok Sleman Yogyakarta. Naskah

Publikasi Sekolah Tinggi Ilmu Keperawatan 'Aisyiyah Yogyakarta.

Maya Amaliyah, Rahayu Dewi Soeyono, Luthfiyah Nurlaela, dan Dwi Kristiastuti. 2021. Pola Konsumsi Makan Remaja Di Masa Pandemi Covid-19. Jurnal JTB Vol. 10 No. 1 (2021) 129-137 ISSN: 2301-5012

Marwan, M.R., 2017. Bahaya Makan Terlalu Banyak Makanan Restoran Cepat Saji. [diakses pada 7 Desember 2018].

Masthalina, H., Suhaema, Mizwar, M. 2013. Ketersediaan Uang Saku, Aktivitas dan Pengetahuan Remaja Berhubungan dengan Pola Konsumsi Fast Food di SMAN 1 Mataram. Jurnal Media Gizi Pangan.

Menteri Kesehatan Republik Indonesia. 2014. [16] Mihrete, K. 2012. Association Between Consumption and Obesity and High Blood Pressure among Office Workers. Dissertation. Walden University.

Mustikaningsih, D., Hartini, T.N.S. \& Syamsiatun, N.H. 2015. Persepsi tentang Fast Food dan Frekuensi Konsumsi Fast Food sebagai Faktor Risiko Terjadinya Obesitas pada Remaja di Yogyakarta. Jurnal Nutrisia Vo. 17 No. 2.

Nusa, A.F.A. \& Adi, A.C. 2013. Hubungan Faktor Perilaku, Frekuensi Konsumsi Fast Food, Diet dan Genetik dengan Tingkat Kelebihan Berat Badan. Media Gizi Indonesia Vol. 9 No. 1.

Octavia, L.I., 2018. Dampak Konsumsi Junk Food Jangka Panjang. [diakses pada 4 Desember 2018].

Odegaard, A.O., Koh, W.P., Yuan, J.M., Gross, M.D. \& Pereira, M.A. 2012. Western-Style Fast Food Intake and Cardiometabolic Risk in an Estern Country. Circulation 126(2).

Peraturan Menteri Kesehatan Nomor 25 Tahun 2014 Tentang Upaya Kesehatan Anak. Jakarta.

Pratiwi, H., Sety, L.O.M. \& Tina, L. 2018. Analisis Faktor Risiko Kejadian Penyakit Fibroadenoma Mammae (FAM) di Rumah Sakit Umum Daerah Bahteramas Provinsi Sulawesi Tenggara Tahun 2017. Jurnal Ilmiah Mahasiswa Kesehatan Masyarakat Vol. 3 No. 2.

Pratiwi, M.D. 2010. Hubungan Pola Makan Fast Food dengan Kejadian Hipertensi pada Usia Produktif di Dusun Tegal Ngijon Sumber Agung Moyudan Sleman Yogyakarta. Naskah Publikasi Sekolah Tinggi Ilmu Keperawatan 'Aisyiyah Yogyakarta.

Putra, S.R. 2015. Buku Lengkap Kanker Payudara. Yogyakarta : Laksana.

Purohit, G., Shah, T. \& Harsoda, J..M. 2015. Prevalence of Obesity in Medical Students and Its Correlation with Cardiovascular Risk Factors : Emergency Alarm for Today?.
Kathmandu University Mecidal Journal Vol. 13 No. 4.

Rafiony, A., Purba, M.B. \& Pramantara, I.D.P. 2015. Konsumsi Fast Food dan Soft Drink sebagai Faktor Risiko Obesitas pada Remaja. Jurnal Gizi Klinik Indonesia Vol. 11 No. 04.

Sari, R. W. 2008. Dangerous Junk Food : Bahaya Makanan Cepat Saji dan Gaya Hidup Sehat. Yogyakarta : Penerbit O2.

Septiana, P., Nugroho, F.A. \& Wilujeng, C.S. 2018. Konsumsi Junk Food dan Serat pada Remaja Putri Overweight dan Obesitas yang Indekos. Jurnal Kedokteran Brawijaya Vo. 30 No.1.

Semiun, Y. 2006. Kesehatan Mental 1. Yogyakarta : Penerbit Kanisius.

Setyawati, V.A.V. \& Rimawati. 2016. Pola Konsumsi Fast Food dan Serat sebagai Faktor Gizi Lebih pada Remaja. Unnes Journal of Public Health Vol. 5 No.3.

Shah, T., Purohit, G., Nair, S.P., Patel, B., Rawal, Y. \& Shah, R.M. 2014. Assessment of Obesity, Overweight and Its Association with The Fast Food Consumption in Medical Students. Journal of Clinical and Diagnostic Research. Vol. 8 No. 5.

Yilmaz C, Gökmen V. 2020. Neuroactive Compounds in Foods: Occurrence, Mechanism and Potential Health Effects. Food Res. 128:108744.

World Health Organization. 2014. Health for The World's Adolescents : A Second Chance in The Second Decade. Geneva : WHO Document Production Services. 